DOI: $10.30842 /$ ielcp230690152440

Elena Parina

(Institute of Linguistics, RAS, Moscow / Philipps-Universität Marburg)

\title{
«MULTIPLE ORIGIN» AS A USEFUL CONCEPT FOR ANALYSING BORROWINGS INTO MIDDLE WELSH
}

This contribution advocates for leaving the notion of borrowings as once-and-for-all processes and argues in favour of the mechanism of multiple inputs. This perspective lies behind etymological analysis of loanwords into Middle English in the Oxford English Dictionary and the analysis of some Middle Welsh words suggests that it could be even more plausible for medieval Wales given its multilingual situation, where Latin, Middle English and Anglo-French functioned as lexical donors. As illustrations for the notion of multiple origins some loanwords in a religious text Ystoria Lucidar in the $14^{\text {th }}$ century manuscript Oxford, Jesus College MS. 119 are analysed on an exemplary basis. Although all of them are classified as borrowings from Middle English or possibly Anglo-French in Geiriadur Prifysgol Cymru their correspondence to the phonetically similar Latin equivalents could suggest at least a reinforcement of reborrowing of words in the process of translation that is a specific locus of language contact.

Keywords: Middle Welsh, loanwords, translations in Middle Ages, Latin, Middle English, language contact.

Е. А. Парина

(Институт языкознания РАН / Марбургский университет)

\section{Многократные заимствования из разных источников - к методологии анализа заимствований в средневаллийский язык}

В статье предлагается учитывать возможность неоднократного заимствования при этимологическом анализе средневаллийских лексем. Для среднеанглийского языка этот подход убедительно применяется в Oxford English Dictionary, в валлийском словаре Geiriadur Prifysgol Cymru этимологические пометы делаются исходя из предположения о единственности возможного источника заимствования. Анализ отдельных лексем в религиозном тексте Ystoria Lucidar в рукописи 14-го века Oxford, Jesus College MS. 119, маркированных в словаре как заимствования из среднеанглийского (или, возможно, французского), но при этом соответствующих в латинском оригинале лексемам, к которым в конечном итоге восходят и английские слова, заставляет предположить как минимум возможность расширения значения или повторного их заимствования при переводе.

Ключевые слова: Средневаллийский язык, заимствования, перевод в средние века, латынь, среднеанглийский язык, языковые контакты. 
Borrowings into Welsh have been already discussed within the Indo-European Linguistics and Classical Philology Yearbook (see Falileyev 2002, Parina 2008) and since then further loanwords in Middle Welsh texts were analysed by Falilieyev (2017, 2018a, $2018 b)^{1}$. Loanwords in particular Middle Welsh texts were studied for Ystoria Bown in (Poppe, Reck 2008: 144-147) and the distribution of loanwords in Ystoryaeu Seint Greal by Zimmermann (2020: 215-298). In the religious text Ystoria Lucidar, found i.a. in the manuscript Oxford, Jesus College MS. 119, also known from its colophon as Llyfr Ancr Llanddewi Brefi, dated 1346, hereinafter $\mathrm{LlA}^{2}$, many loanwords expectedly are found (see Rowles 2008: 155-157). This text is a translation from Latin (see the discussion of this text in Parina 2018) and since translations are, as shown by Kranich, specific loci of language contact (Kranich 2014), the analysis of loanwords in this particular environment could provide a glimpse into the mechanisms of borrowing and using these words in the target language. In this contribution I will draw attention to four words used in Ystoria Lucidar (person 'person', swbstans 'substance', presentiaw 'to present' and emendau 'to amend'), that are classified as borrowings from (Middle) English or Anglo-French in Geiriadur Prifysgol Cymru (GPC), but could possibly profit when treated as words of multiple origin - this concept, used in the Oxford English Dictionary, could be, as I will argue, very useful for the analysis of some loanwords borrowed into Welsh.

For Middle English '[i]n very many cases, we cannot say with complete confidence that a word is from French rather than Latin, or vice versa, and in most cases composite origin from both languages seems the likeliest scenario (Durkin 2014: 236-7). French itself had a complex history of interaction with the Latin vocabulary, consisting both of the development of spoken Latin and later borrowings from Latin, which resulted in a 'complex layering in the vocabulary of French, which in turn has fed into some even more complex layering in the vocabulary of modern English' (Durkin 2014: 237). For multilingual Wales in the $13^{\text {th }}-14^{\text {th }}$ century (see Falileyev 2004), where Anglo-French, Latin and Middle English were possible lexical donors for Welsh, the issue of layering is even more complex.

${ }^{1}$ This study partly results from the project 'Translations as language contact phenomena: studies in lexical, grammatical and stylistic interference in Middle Welsh religious texts', led by Prof. Erich Poppe at the Philipps-Universität Marburg, supported by the Fritz Thyssen Foundation.

${ }^{2}$ See forthcoming publication Parina\&Poppe (in preparation). 
As one complex example of a continuing influence both from French and Latin Durkin discusses the English word person (Durkin 2014: 248). He analyses its different senses (such as 'an individual human being' and 'each of the persons of the Trinity (in Christian theology)') and shows how they appear in different texts and then are not attested for a long time, after which they might be reborrowed, giving as one possible explanation that 'new senses continued being borrowed from the source language' (ibid.). OED (s.v. person) expresses this idea in the following way: 'Of multiple origins. Partly a borrowing from French. Partly a borrowing from Latin'.

Welsh person is being analysed in GPC as borrowing from Middle English person(e) or a direct borrowing from Old French (s.v. person), that has parallels to Middle Cornish and Middle Breton person. Despite these parallels in all the British languages it cannot be an old common borrowing from Latin into British, since Latin internal $\bar{o}$ underwent phonetic changes (as in Latin fôrma $>$ Welsh ffurf) in the old borrowings (Jackson 1953: 307-8). Nevertheless it seems to be natural to suggest that the theological sense, at least, is influenced by Latin, which was the language of religion of the time. This sense is registered in Welsh already in the $13^{\text {th }}$ century and can be seen in L1A in the explanatory translation of the Athanasian Creed:

(1) Alia est enim persona Patris alia Filii, alia Spiritus Sancti

For there is one Person of the Father; another of the Son; and another of the Holy Ghost.

Ac vrth hynny amgen y6 personn y tat. A pherson y mab. Ac amgen y6 person pob vn ohonunt. A pherson yr yspryt glan. (LlA $120 \mathrm{v})$

Therefore different are the person of Father and the person of Son, and different is the person of each of them from the person of the Holy Ghost.

In Ystoria Lucidar text in LlA it is used in the sense 'person, character', as in the introductory sentence with no Latin equivalent in the assumed source:

(2) *GWeithret y llyuyr h6nn a berthynn ar d6y bersson. nyt amgen. ar disgybyl yn gouyn. ac ar yr athro yn attep. (L1A 5r)

The work of this book relates to two persons, namely, to the Disciple questioning, and to the Master answering.

It is also used referring to Christ, in equivalent to the Latin persona: 
(3) [in answer to the question whether Christ was full of joy after the resurrection]

Quodammodo habet, quodammodo non habet. Quantum ad sui personam, plenissimum (Lefèvre 1954: 393)

$\mathrm{O}$ beth y mae. o beth arall nyt ydi6. her6yd y berson e hun y mae ida6 yn gyfula6n. (L1A 21v)

He was partly, and partly not. As for His own person, He has full [of joy]

It is therefore viable to suggest that we see in the case of the Welsh word person a multi-layered borrowing, both from Middle English or Anglo-French (I will not touch upon this distinction in this contribution, for some arguments see Rowles 2008: 269) and from learned Latin — a source sometimes denoted in GPC (as suggested for ystoria ' bnth. dysg. Llad. historia'), but rather rarely. In this case, however, the borrowing seems to be established in its polysemy in the language before the time of translation, as attestations in GPC show.

Another possible example of a word of multiple origin found in Ystoria Lucidar is the verb emendau (already attested in the $13^{\text {th }}$ century, in religious and legal contexts), for which GPC suggests a Middle English origin. In the LlA text we find this verb three times, once it corresponds to Latin emendare and twice to corrigere:

(4) [in explanation on the reasons why the evil prosper]

Kadarnn vyddant. yn gynntaf oc ev hachos e hunein. megys y gallont g6pplav y drygyev y maent yn y karv. Yr eilweith. o achos y rei kamweda6c oe hamdiffynn wyntev yn y dr6c. Y tryded achos y gospi onadunt yr etholedigyon. Ac oe emendanav oe drycweithredoed. (LlA 28r)

Potentia splendent primo propter se ipsos, ut mala quae amant potenter expleant; secundo propter reprobos, ut eos in malis defendant; tertio propter electos, ut eos castigent et a malis actibus emendent. (Lefèvre 1954: 393)

They are strong, first, for their own sake, so that they may fulfil the evils that they love; secondly, for the sake of the iniquitous, to protect them in their evil. The third reason is to chasten the elect by them, and to correct them from their evil deeds.

(5) [Do the souls pray for their kinsmen?]

Y rei g6iryon a weddiant dros y rei a garassant yn yr argl6yd. neu dros y rei a al6ei arnunt oe diffryt rac dr6c. Ac oe rydhau o brouedigaeth $\mathrm{y}$ byt. Ac oe hemenda6 od ydynt yg kyfueilornn megys y delynt oe kytymeithas ar hynt. (L1A 51v)

Justi orant pro his quos in Domino amaverunt vel pro his qui eos invocabunt, ut a malo serventur et a mundi temptamentis liberentur 
et, si in errore sunt, ut corrigantur et eis celerius associentur. (Lefèvre 1954: 450) ${ }^{3}$

The just pray for those they loved in the Lord, or for those who called upon them to deliver them from evil and to free them from the temptations of this world, and to correct them if they have erred, so that they may speedily come from that error to their society.

The OED entry for emend shows that the attestations for this English word (of Latin origin) are rather late, starting from c1450. The variant amend (from Old French amende-r) is attested earlier (from the $13^{\text {th }}$ century) but would be more problematic phonetically as a source for the Welsh word. It would therefore be worth suggesting, as in the case of person, that learned Latin should be considered as one of the sources for the Welsh word.

These two words were used in Welsh prior to the translation of Ystoria Lucidar. The next two words are much less frequent and are first attested in our manuscript, according to GPC.

The word swbstans is used in Ystoria Lucidar twice, in the discussion of the two elements man was created from that I quote with abbreviations:

(6) O ba beth y krewyt dyn.

o gedernnyt corffora6l. ac vn ysprydawl. corffora61

or petwar defnyd. megys y byt. Ac am hynny y gelwir ef y byt bychan. [...] a llyna gallv corffora61.

y substans ysbryda61 a gredir y vot or tan ysbryda6l. yn yr h6nn y dangossir [11r] delw ac eilun du6.

[...] A llyna y substans ysbryda61 ef. (L1A 10v-11r)

D. Unde?

M. De spirituali et corporali substantia.

D. Unde corporalis?

M. De quatuor elementis; unde et microcosmus, id est minor mundus, dicitur. [...] Haec est substantia corporalis.

D. Unde spiritualis?

M. Ex spirituali igne, ut creditur, in qua imago et similitudo Dei exprimitur.

[...] Haec est substantia spiritualis. (Lefèvre 1954: 371)

D. Of what was man created?

M. Of bodily and spiritual strength/substance:

the bodily

of the four elements, like the world; and, therefore, he is called the "little world [...]And that is his bodily property.

\footnotetext{
${ }^{3}$ The same equivalence Latin corrigere : Welsh emendau is found on f. $32 \mathrm{v}$.
} 
His spiritual strength and condition is believed to be from the spiritual fire, wherein is shown the image and likeness of God.

[...] And that is his spiritual substance.

We can see that in this passage the translator struggles with finding an adequate equivalent to the very complex and abstract notion expressed in Latin with substantia. He uses three words for it. First, cedernyd (a derivative from cadarn 'strong'), meaning 'strength, power, potency, might, fortitude', and interestingly as 'substance, substantive, noun' in the Gramadegau'r penceirddiaid, Bardic grammars, which shows a similar semantic extension. Secondly, gallu, a polysemous word meaning 'ability, power; property'. These two words are of Celtic origin, belong to the basic vocabulary and the translator extends their meaning. And the end of the passage he uses a loanword substans - GPC suggests it to be a borrowing from Middle English substance or directly from AngloFrench and notices that the phonetic value of $\langle\mathrm{u}>$ is unclear. The form of the word suggests indeed the knowledge of a Middle English or Anglo-French word, but the direct equivalence with the Latin substantia used in the assumed source makes it possible that we see here one of these inputs of the multiple borrowing - which is proposed for the English counterpart (OED, s.v. substance): 'Of multiple origins. Partly a borrowing from French. Partly a borrowing from Latin. Etymons: French substans; Latin substantia'.

The last word to be discussed in this article, presentya6 'to present' appears, according to GPC, only once in Middle Welsh (the Welsh Prose 1300-1425 corpus (Luft et al. 2013) shows its use only in the parallel passages of the Ystoria Lucidar text in other manuscripts, its next usage is attested only in the Llyfr Gweddi Gyffredin 'The Book of Common Prayer' of 1567).

(7) Eu damunet y6 y g6edi kannys beth bynnac a damunont 6y ae caffant yn diannot. Ae g6edi wyntev y6 presentya6 y grist poennev y corff. neu y da a wnnaethant yrda6. (L1A 51v)

Desiderium eorum est oratio illorum. Quidquid enim desiderant, sine dilatione percipient. Illorum etiam orare est cruciatus corporis vel bene gesta pro Christo Deo repraesentare III.26 (Lefèvre 1954: 451)

Their desire is their prayer, for whatsoever they desire they receive immediately from God. And their prayer is to present to Christ the torments of the body or the good that they did for His sake.

According to GPC this is a borrowing from English (to) present (s.v. presentiaf). As we see in the assumed Latin source reprae- 
sentare, it seems to be plausible to argue here again for a case of an input from Latin, as is suggested for the English verb in OED (s.v. present, v. - 'Of multiple origins. Partly a borrowing from French. Partly a borrowing from Latin').

In his book Durkin (2014: 250) claims against the 'considerable strain of the notion of lexical borrowing as once-and-for-all process: many of these word histories are highly suggestive of multiple inputs, in some cases from (Anglo-)French and in others from Latin, sometimes in literary contexts and sometimes in spoken ones [...]'. It seems that this notion of the once-and-for-all process of borrowing lies behind the etymological information in GPC. For English Durkin (2014: 251) argues that '[i]t is the combination of our knowledge of the multilingual language contact situation with our detailed knowledge of the histories of each word in Latin, French, and English that makes the case for multiple inputs compelling, even if the precise mechanisms normally remain uncertain in individual cases'. The socio-linguistic situation in medieval Wales is even more complex which makes the case for multiple inputs the more compelling and the study of translations into Welsh could help to grasp the precise mechanisms in some individual cases.

\section{References}

Durkin, P. 2014: Borrowed words: A history of loanwords in English. Oxford.

Falileyev, A. 2002: [Latin borrowings in Old Welsh. A chapter in historical lexicography of Welsh]. Colloquia classica et indo-europeica, 3: 347-366.

Фалилеев, А. И. 2004: Латинские заимствования в древневаллийском. (Глава из исторической лексикологии валлийского языка). Colloquia classica et indo-europeica, 3: 347-366.

Falileyev, A. 2004: [Reading in multiligual situation: Wales in the late $14^{\text {th }}$ century]. Novoe literaturnoe obozrenie, 68:4.

Фалилеев, А. И. 2004: Круг чтения в условиях многоязычия: Уэльс в конце XIV века. Новое литературное обозрение, 68:4.

Falileyev, A. 2017: Sylwadau ar Rai o Linellau Dafydd Nanmor. Dwned, 23: 121-149.

Falileyev, A. 2018: [Medieval Welsh translation of Relatio Fratris Odorici: some aspects of research]. Indo-European Linguistics and Classical Philology, 22: 1288-1301.

Фалилеев, А. И. 2018: Перевод Relatio Fratris Odorici в средневековом Уэльсе: некоторые проблемы изучения. Индоевропейское языкознание и классическая филология, 22: 1288-1301.

Falileyev, A. 2018: Cywyddwyr a'u cywyddau: sylwadau amrywiol. Dwned, 24: 43-66. 
GPC, 2014: GPC Online. Geiriadur Prifysgol Cymru. University of Wales Centre for Advanced Welsh \& Celtic Studies. http://welshdictionary.ac.uk/gpc/gpc.html

Jackson, K. 1953: Language and history in early Britain. Edinburgh.

Kranich, S. 2014: Translations as a Locus of Language Contact. In: Translation: A multidisciplinary approach. London, ed. by J. House. London, NY, 96-115.

Lefèvre, Y. 1954: L' Elucidarium et les lucidaires. Contribution, par l'histoire d'un texte, a l'histoire des croyances religieuses en France au moyen age. Paris.

Luft, D., et al. 2013: Rhyddiaith Gymraeg 1300-1425.

http://www.rhyddiaithganoloesol.caerdydd.ac.uk.

OED, 2020: Oxford English Dictionary. OED Online. Oxford University Press. https://www.oed.com/

Parina, E., 2008: [Latin borrowings in Modern Welsh]. Indo-European Linguistics and Classical Philology, 12: 364-370.

Парина, Е. А. 2008: Латинские заимствования в современном валлийском языке. Индоевропейское языкознание и классическая филология, 12: 364-370.

Parina, E., 2018: The good, the bad and the translator: the concept of predestination in a Middle Welsh translation of Elucidarium. IndoEuropean Linguistics and Classical Philology, 22, 1003-1012.

Parina, E., Poppe, E. Translating devotion in medieval Wales. Studies in the texts and language of Llyfr Ancr Llanddewibrefi, in preparation.

Poppe, E., Reck, R., 2008: A French romance in Wales: Ystorya Bown o Hamtwn: processes of medieval translations. Zeitschrift für celtische Philologie, 56: 129-164.

Rowles, S. 2008: Yr Elucidarium: Iaith, Strwythur, Cynnwys ac Arwyddocâd y Cyfieithiadau Cymraeg. PhD thesis. Prifysgol Cymru, Aberystwyth. http://cadair.aber.ac.uk/dspace/handle/ 2160/1877.

Zimmermann, C. 2020: Ystoryaeu Seint Greal - Zwischen Übersetzung und Adaption. PhD thesis. Philipps-Universität Marburg. Marburg. 